\title{
PESANTREN AS A BASIS FOR INTERNALIZATION OF PLURALISTIC VALUES FOR PREPARING A DEMOCRATIC CITIZENS IN A DIVERSE SOCIETY
}

\author{
ABDUL ROHMAN ${ }^{1}$ \\ Universitas Islam Negeri Walisongo Semarang
}

\section{Abstract}

Indonesia, as a pluralistic country, has potentialities of conflict at anytime as frequent violence has happened in Indonesia. Therefore, pluralism value has to be early introduced to the students in order to make them accustomed to a democratic attitude, and in turn, able to live in the diverse society harmoniously. Education has an important role to instill pluralism and tolerance values to students. It is a strategic way to socialize the values of tolerance, moderation, respect, and empathy, and to develop an attitude for learners in responding to the pluralism. This study will qualitatively discuss the role of pesantren in internalizing pluralism values to students in responding to a diverse society. It focuses on how the curriculum is constructed, instruction is done for the sake of creating a school culture for holding education that addresses pluralistic values. This study shows that pesantren with a pluralism based religious education is an effective basis for internalizing the values of pluralism to perform tolerance and inclusiveness to prepare the students to live in a pluralistic or diverse society.

Indonesia, sebagai negara majemuk, memiliki potensi konflik yang bisa terjadi sewaktu-waktu dan hal ini bisa berujung pada kekerasan. Oleh karena itu, nilai pluralisme harus diperkenalkan lebih awal kepada siswa agar membuat mereka terbiasa dengan sikap demokratis, dan pada gilirannya, mampu hidup secara harmonis

Corresponding author; email: ${ }^{1}$ abdulrohman@walisongo.ac.id.

ISSN 0852-7172 (p) 2461-064X (e) 
dalam masyarakat yang beragam. Pendidikan memiliki peran penting untuk menanamkan nilai pluralisme dan toleransi kepada siswa. Pendidikan merupakan media strategis untuk mensosialisasikan nilai toleransi, moderasi, rasa hormat, dan empati, dan untuk mengembangkan sikap bagi peserta didik dalam menanggapi pluralisme. Studi kualitatif ini akan membahas peran pesantren dalam menginternalisasikan nilai pluralisme kepada siswa dalam menang gapi masyarakat yang beragam. Studi difokuskan pada bagaimana kurikulum dibangun, pembelajaran dilakukan untuk menciptakan budaya sekolah dalam menyelenggarakan pendidikan yang membahas nilai-nilai pluralistik. Studi ini menunjukkan bahwa pesantren dengan pendidikan agama berbasis pluralisme merupakan dasar yang efektif untuk menginternalisasikan nilai-nilai pluralisme untuk memiliki sikap toleransi dan inklusivitas untuk mempersiapkan siswa hidup dalam masyarakat majemuk.

Keywords: democracy; education; internalization; pesantren; pluralism.

\section{Introduction}

Democratic society is an ideal of every nation state in the world, including Indonesia (see UUD 1945). ${ }^{2}$ It refers to a nation in which each individual has a freedom, dignity, and equality, and he can communicate and express to another. Democracy is a process of decision-making to achieve a coexistence of conceivable participatory and to consider the existence of plurality values in society (Wahid 2009). Historically, portrait of this society can be seen in American society (Azizy 2000) in the moder $n$ perspective, or in the community of Medina (Hamim 2000, 114-15) in the Islamic perspective. The Medina is a community established by the Prophet Muhammad often known as

${ }^{2}$ Even, in the Indonesian National Education System, it is emphasized that education is aimed at "making an individual to be faith in and fear of God, noble, healthy, knowledgeable, skilled, creative, independent, and become democratic and responsible citizens. See (UU Republik Indonesia No. 20 2003) on National Education System, verse 3. 
civil society which, in spite of the plurality in religion, tribe, race, language, and culture, its people can live in harmony, peace, and mutual respect for the rights and obligations, and uphold the values of tolerance.

Indonesia is a pluralistic country, in ethnicity, religion, race, culture, or language. Ethnically, Indonesia has more than 151 tribes that live from Sabang to Merauke. In religion, there are many religions in Indonesia. The officially recognized religions in Indonesia are Islam, Catholics, Christianity, Hinduism, Budhism. In addition, there are many local beliefs growing in the society. Each religion has diversities as a consequence of the doctrine of religi ous discourse in history. In language, beside the national language, i.e. Indonesia, there is also a variety of local languages each of which has different dialect and color (Elizabeth 2007, 5).

Plurality is a boon, because it shows the rich culture ${ }^{3}$ but it also holds the potentiality to conflict, and even it can cause unrest, and anarchism that are detrimental to society, so as it brings issues and problems ${ }^{4}$ that will disrupt national unity, and consequently the ideal democratic society would be difficult to actualize, if it is not managed well. The Susetiawan's (Suseti-

${ }^{3}$ Satjipto Rahardjo (Musahadi 2007, vi) stated that Indonesia is a fully equipped laboratory and promising to study the social sciences and humanities.

${ }^{4}$ Some incidents in various places in Indonesia, both in the form of internal conflicts Muslims, as well as conflicts between people and other tribes, were evidence of the pluralities. Some violences ranging from Sambas, Banyuwangi, Situbondo, Poso, Ambon; church bombings on Christmas Eve and New Year; Bali bombing; violence against Ahmadiyya in Parung, Lombok and Kuningan; to dispute the establishment of houses of worship and acts of violence in Bekasi, were also a living testimony to the negative side of the pluralisties. In addition, the annual report on religious life in Indonesia in 2012, released CRCS-UGM during 2002 there were 22 cases, some of which occurred in Bogor, Makassar, West Sumatra, Aceh, Lampung and Purbalingga, also reinforced the negative side of the pluralities (Rohman 2016; Zainuddin 2015). 
awan 2000), Susan's (Susan 2009), Afrizal's (Afrizal 2007), Siahaan's (Siahaan 2002) and Yuwinanto's studies have proved that plurality often cause conflict because it is not well-managed (Yuwinanto 2004). To overcome these problems, education become an important element to consider.

Education plays an important role in shaping a mode of thought of learners and society. It is a key of the existence, survival, and global security (Tilaar and Nugroho 2008, 267) as well as an effective instrument for the establishment of the world-view of a person. Education is a strategic pillar to disseminate the values of tolerance, moderation, respect, and empathy, and to develop an attitude of non-violence for learners. Schools become microcosm that reflects the situation that lives and thrives in society so that the activities and learning practices in schools also need to reflect the realities that exist in society. Within this framework, the study of pesantren, a form of Islamic education in Indonesia, as the basis for internalizing a pluralism value argues.

This paper is a qualitative study (Moleong 2007, 3) that examines a 'case' in a natural context, which is reviewing a program, event, activity or an individual (Creswell 1998, 61). The study is conducted in Modern Islamic Boarding School (PPMI) Assala am Surakarta, Central Java. Is pesantren, as typical Indonesian Islamic institution, able to serve as an instrument to instill a value of pluralism to prepare students becoming democratic citizen in order to live in a diverse society? How do they design a curriculum, how the curriculum is implemented, and how is the infrastructure laid out?

\section{Review of Literatures}

Pluralistic Value as the Basis for Preparing Democratic Citizen to Live in Diverse Society 
Pluralism is derived from the words "plural" that means diverse, and "ism" that means ideology, so it means the state ideology of plural society. It is defined as "a framework of interaction in which groups show sufficient respect and tolerance of each other, that they fruitfully interact without conflict or assimilation".(Rohman 2016) Pluralism also refers to: (1) the existence of groups that differ in ethnic, cultural patterns, religion and others within a country, and (2) policies that support the protection of these groups in the state or the public (Neufeldt 1995, 1040).

Pluralism is a view, an understanding of something as completely diverse; everything is understood and approached in multidimensional approaches in which there is no single paradigm (Abdullah 1995, 104). Imarah defines that pluralism is diversity that is based on the specific characteristics (Thoha 2007, 129). Madjid even asserts that pluralism is understood not only as plural, diverse society consisting of various races and religions, but also as of diversity within the bond of civility (Rachman 2001, 39).

In relation with religiousity, there are several explanations of pluralism. Religious pluralism can be taken through the three religious attitudes, namely: the exclusive, inclusive, and pluralist one. With these attitudes, other religions have the own way to achieve the same truth in different ways (Madjid 1998, 56). With plurality, believers demand not only to recognize the existence and rights of other religions, but also to involve in the effort to understand the differences and similarities in order to achieve harmony and diversity (Shihab 1998). In relation with religion, pluralism refers to certain attitudes that support the reality of religious diversity (Mukhlis 2004, 16). Religious pluralis $m$ is related to a particular theory of the relationship between various religious traditions they claim to be different and competing (Eliade 1995, 331). 
The views, thinking, and understanding of something are diverse; everything is understood and approached in multidimensional ways, there is no single paradigm. These understandings will imply on the individual's attitude and behaviour that he will not easily blame the other that is different from himselves; he will not be easy to claim that the truth is only hers because the truth is multifacet, the truth can be approached from all sides. In contrast, the narrow sense, single paradigm, subjective views would only lead to blame others that are different from themselves. Rodney Stark states that "the claim of monotheism is particularistic-subjective" has frequently led to conflict (Zainuddin 2015).

\section{The Pesantren as Basis for Internalization of Pluralistic Value}

The word pesantren stems from "santri" which means one who seeks Islamic knowledge. It refers to a place where the santri devotes most of his or her time to live in and acquire knowledge (Mas'ud 2002, 10).

Pesantren which is the oldest form of Islamic education in Indonesia (Ridwan 1993, 104) and one of the indigenous cultures of Indonesia (Nafis 1998) is grouped into five types, namely A, B, C, D and E type (Ziemek 1986, 104-9). The first is pesantren of A type hat only has main components: a mosque, kyai (priest), and student. Component of boarding school (pondok) does not exist yet in this type. If there are students who want to live in pesantren, kyai accomodates them to his home. The second is pesantren that has a component of $\mathrm{B}$ type: mosques, kyai, students, and cottage or dorm. Pesantren type of A and B can be categorized as a traditional pesantren (salafy) (See Aly 2011, 177). This type more focuses on teaching classical texts (kitab kuning) and moral education as the core of education, it does not prepare the students to face broader social issues in 
a changing society (See Lukens-Bull 2004, 84-85). The third is pesantren that has a $\mathrm{C}$ type: mosques, kyai, students, cottage, and madrasah. This type of $\mathrm{C}$ can be categorized as modern pesantren (khalafy) which teaches the "secular", religious and moral education. The secular subjects are: English, mathematics, science, and others (Lukens-Bull 2004). The fourth is pesantren of $\mathrm{D}$ type which is characterized by three things: a $\mathrm{C}$ type $p e-$ santren components plus skill programs, such as the agricultural sector skills, sewing, electrical engineering, workshop, carpentry, and others. The fifth is pesantren with E type which has facilities like D type plus public schools and colleges.

These various types of pesantren, however do not only concern with a nursery center and religious practice but also address to teach Islamic sciences (Abdullah 1998, 3) and other sciences. In fact, pesantren is also a system of social dynamics, cultural and religious Islamic society, even it has formed a subculture (Raha r djo 1985, 25). Then pesantren is not only a physical building in which students learn religious knowledge, the kitab kuning, the students, and kyai, but also a community, people who live around pesantren, and form a pattern of cultural, social, and religious relations. With these characteristics, pesantren is essentially a form of integration between family, community and school (madrasab), in which Ki Hadjar Dewantoro called “Tri Pusat Pendidikan” (Center of education). In the perspective of values internalization (including values of pluralism), family, school, and society are an important factor to internalize pluralism values to the children. In the perspective of the Act on National Education System, education is held through formal, informal and non-formal education (UU Republik Indonesia No. 20 2003). It is responsible of families, communities and schools (Dewantara 1962, 100). Oladipo (2009) stated that "each child from birth, by virtue of his environment, belongs to 
a significant group. Familiy members, friends, relatives, teachers and administrators play a major role in formation of the character of each child". However, most parents hand over their children to school, meanwhile school focuses more on cognitive and psychomotoric domain to the learners in teaching-learning process, so affective domain is often neglected. This integrated responsibility can directly overcome the phenomena that some education processes are dominated by the cognitive, psychomotor in one side, and affective domain is neglected on the other side (Muhaimin 2009, 23; Sjarkawi 2011, 37; Mas'ud 2002; Abdullah 1998). In fact, value as a part of an affective domain is very important. It is more vital than the others in education (Mardapi 2012, 154). Internalizing value will be effective if it is done with integrative approach (Oladipo 2009), and it has been implemented in the pesantren.

With integralistic approach, the value internalization is the mission of each subject; it is implemented through daily learning in school; it is not taught in specialized subjects (Nurchaili 2010). Internalizing value requires an ongoing process, which is done through a variety of subjects in the curriculum, even it can be integrated in the activities of extra-curricular and co-curricular activities. The pattern of such education has been applied in schools that apply a pesantren system which implements habituation and modeling (Rohman 2014). The goal of pesantren is not merely cognitive and psychomotor ability, but the most important is the formation of character and personality (Dhofier 1994, 21).

\section{Findings}

Internalizing a pluralist value in Pesantren Assalaam

a. Modern Islamic Boarding School Assalaam at Historical Glance 
Modern Islamic Boarding School Assalaam was established on July 17, 1982 by H. Marzuki Abdullah (d. 1990) and his wife, Hj. Siti Aminah in the Village Punggawan, Jalan Yosodipuro No. 46 Surakarta. At first, it was a form of activities of religious studies to the community named Majlis Pengajian Islam (MPI). Because of positive response of society, he upgraded his institution to a legal entity, named the Foundation of Majlis Pengajian Islam. The founders were $\mathrm{H}$ Abdullah Marzuki, $\mathrm{Hj}$ Siti Aminah, KH Jamaluddin Abu Amar, H Muh Umar Nahdi, Drs Ahmad Syamsuri, and Mohammad Chozin shidiq.

Pesantren which seeks to integrate the two schools predecessors in Surakarta, namely Al-Islam and Al-Mukmin, was established with the purpose "to explore and develop the science and the teachings of Islam sourced from al-Quran and al-Sunnah and make them happen in life and everyday life", with the main activities: teaching, education and social services. The teaching of religion was intended for children, students, and communities, both in mosque activities and in programs of Ramadan. Educational activities include Arabic languages courses, religious studies, sports, and skills. Activites in social services are: clinic, addessing poor children and sevicing for the dead.

A positive response of the community of Surakarta had encouraged H Marzuki Abdullah to establish a formal education in the form of Madrasah Diniyah Awwaliyah (MDA), later successiv ely established Madrasah Tsanawiyah (MTs), Madrasah Aliyah (MA), High School (SMA) and Vocational High School (SMK).

Modern Islamic Boarding School Assalaam is managed with a boarding school model that requires all students to live in a pondok (dorm), so-called Modern Islamic Pesantren. It was called "pesantren" because it implemented a system as the traditional model in general, and the "modern" because it applied the 
educational system as in modern schools. The existence of Modern Islamic Boarding School Assalaam is actually a constructive criticism of the concept of national education on the one hand, and pesantren system on the other hand. In the view of Abdullah Muzakki, national education is unsufficient charge of Islamic religious education. In fact it is very important to form children's mentality and personality. While pesantren is more focused on Islamic religious education and is unable to portray itself as a clean, tidy educational institution, and it is also unable to integrate science to the students. Modern Islamic Boarding School Assalaam tries to integrate two models of educational system, i.e. salafiyyah (traditional) and hadithiyyah (modern).

These institutions use two languages in daily communication, namely Arabic and English. Hence, the name of the Modern Islamic Boarding School (PPMI) Assalaam is also translated into two languages, namely Arabic "al-Ma'had al-'Ashriy al-Islāmiy Assalām” and English "The Modern Boarding School of Islam Assalaam.

Modern Islamic Boarding School Assalaam's curriculum is developed based on the vision, mission and objectives that have been formulated. Its vision is: "the establishment of a human being who has a balance of spiritual, intellectual, and moral towards $\bar{u} l u l$ albāb generation of highly committed to the advancement of the people on the basis of al-Quran and al-Sunnah". Its mission are: (1) to conduct Islamic education that is process-oriented, highly competeitive, and based on the spiritual, intelectual, and moral attitude; (2) to develop a working patterns based on a boarding school with islamic professional management; (3) to create the atmosphere of an orderly, safe, and peaceful and full of ideals; (4) to enhance the positive image of the pesantren's science and information technology as well as Islamic culture; (5) to undertake efforts to progress the regeneration of the 
people towards civil society. Based on the vision, and mission, then Modern Islamic Boarding School Assalaam's objectives are formulated namely: (1) to form a condidate of ulül albab who actively participate in efforts commanding the good, avoiding the evil, (2) to develop an attitude of modern life by al-Quran and al-Sunnah in sincerity, discipline, order, cleanliness, peacefulness, and models, (3) to master the basics of science and technology (Kadarusman 2006, 47-51).

According to the founder (H Abdullah Marzuki, Hj Siti Aminah, KH Jamaluddin Abu Amar, Muhammad Chozin Siddiq), stude $\mathrm{n}$ ts of Modern Islamic Boarding School Assalaam must have five basic abilities, namely: (1) extensive understanding of sciences, (2) deep understanding of Islamic knowledge, (3) good attitude and morality, (4) ready to strive in the sake of God (jihād fì sabìlillāh), (5) stands beyond all parties (Kadarusman 2006).

b. Student

Students of Modern Islamic Boarding School Assalaam consist of MTs, MA, SMA and SMK. They have a diverse background in terms of regions of origin. They come from areas throu ghout Indonesia. In general, students come from Java (Central Java, East Java, West Java, Banten, Jakarta, Yogyakarta) which account for about $68 \%$ and outer islands (Borneo, Sulaw esi, Sumatra, West Nusa Tenggara, East Nusa Tenggara, Riau, Lampung, Aceh, Bengkulu, Bali, Papua, Jambi, Aceh, Bengkulu, Maluku) which amounted to 32\% (Aly 2011).

In order to recruit new students, the Modern Islamic Boarding School Assalaam establishes consulates organization whose the $\mathrm{d}$ uty is to disseminate information to those regions. The consulates are: Unasnassko, Isada Semasa, Kartika Persada, Serayu, USTE, Batik Balama. Unanassko is provided to the Surakarta area, Sragen, Boyolali, Klaten, Sukoharjo, Karanganyar; Isada Semesta provided to the area of Semarang, Salatiga and 
surroundings; Kartika Persada is for Kudus area, Jepara, Pati, Rembang, Demak; Serayu is provided to B nyumas, Cilacap, Purwokerto, Purbalingga, Banjarnegara and surrounding areas; USTE is for Tegal, Brebes, and surrounding areas; Batik Balama is for the area of Pemalang, Pekalongan, Batang and surrounding areas. In addition, the organization also serves consulate to exercise an organization maturity within each student.

c. Curriculum

The curriculum of formal school in Modern Islamic Boarding School Assalaam is an integration between the curriculum of the Ministry of National Education, Ministry of Religious Affairs, and pesantren. Modern Islamic Boarding School Assalaam combines models of Modern Pesantren of Gontor Ponorogo, Pesantren of al-Mukmin Ngruki, and Pesantren of Al-Irsyad Semarang (Aly 2011). Briefly, the Assalaam's curriculum can be grouped into two things: a curriculum for kesantrian, programs organized in everyday life in the dorm; the formal school curriculum; and educational programs held in the school. Curriculum of pesantren and school is integratedly organized.

Pesantren's curriculum consists of courses curricular, co-curricular and extra-curricular activities. Curricular activities are focused on aspects of cognitive implemented in schools: (1) Arabic (al-lughah al-'arabiyyah), (2) English (al-lughah al-injilizziyyah), (3) faith ('aqīdab), (4) morality (akblāq), (5) memorizing al-Quran (tahfìdz), (6) Islamic law (fiqh), (7) Islamic history (tarī $k h)$ or Islamic civilization (Thaqāfah al-Islāmiyyah), (8) method of learning (tarīqat al-ta'lim), and (9) reciting al-Quran (qirat al-Quran). Co-curricular activities are focused on aspects of affective, consisting of: (1) reciting al-Quran (qiraat al-Quran), (2) discussion (al-muhädlarah), (3) enrichment and encuragement in language (tazwīd wa tasyjī’ al-lughah), (4) conversation (al-muhādatsah), (5) study of exegeses al-Sunnah (Dirāsah 
al-tafsìr wa al-hadìth), and (6) reading traditional book of pesantren (qiraat al-kutūb). While extra-curricular activities give emphasis on development of talent-interest: activitiy in the field of sports, skill and art. The curriculum schools are expected to produce the output of students who are: (1) able to memorize the al-Quran at least three chapters, namely chapters 1, 2, 30, (2) capable of reading the al-Quran well and clearly, (3) capable of being priests and sermoners, (4) able to communicate in Arabic and English, (5) able to make a speech text in Arabic and English, (6) having a healthy body, independent spirit, sincere, simple, brotherhood, leadership, (7) having a good faith, good moral, well worship, (8) mastering the basics of social and natural sciences, (9) having the basics of computer applications (Kadarusman 2006).

In the formal school, the curriculum consists of two groups, namely the madrasah curriculum (MTs and MA) and school (SMA and SMK). To madrasah, Modern Islamic Boarding School Assalaam adopts curriculum of ministry of religion plus, namely curriculum implemented in MTs and MA in general, but enriched with Assalaam, which multiplies the hours of teaching A rabic language, the use of the Arabic language in teaching subjects faith-morals, Islamic jurisprudence, the al-Quran, al-Sunnah, and SKI. To school (high school and vocational), they implement a curriculum of Ministry of Education plus, namely a curriculum that is implemented in other SMA and SMK, and enriched with typical Modern Islamic Boarding School Assalaam, where all students live in the cottage for 24 hours with educational programs schools (Aly 2011).

Dealing with the content as the element of the curriculum, especially in Islamic studies, Modern Islamic Boarding School Assalaam uses some books, namely: (1) Kitāb al-Tawhid written by Salih Fauzan, (2) Kitāb al-Sīrah al-Nabawiyyah: Durūs 
wa al-Ibār written by Musthofa Siba'i, and the Book Muqaddimah fi al-Thaqāfah al-Islämiyyah written by Mufarrah bin Sulaiman al-Qudsy. These books were adopted from Pesantren of Al-Mukmin. In addition, there are some other books, such as: (1) al-Nabw al-Wadhīh fī Qawā'id al-Lughah al-'Arabiyyah written by Ali Mustofa Amin Ali al-Jarim, (2) Mabāhits fī 'Ulūm al-Quran written by Manna al-Qaththan, (3) Bidāyah al-Mujtahid wa Nihāyah al-Muqtasid written by Ibnu Rusyd, (4) Taisir Mustalah al-Hadith written by Mahmud Thahhan, (5) al-Tarbiyah wa al-Ta'lim written by Mahmud Yunus dan Muhammad Qasim Bakar. These books were adopted from Pesantren Gontor. In addition, PMI Assalaam also adopted the books of alIrsyad pesantren, namely: (1) Aisar al-Tafāsir li Kalām al-'Aliy al-Kabìr written by Abu Bakar Jabir al-Jazairi, (2) al-Mulakhkhas al-Fiqhiy written by Shalih Fauzan dan Mukhtasar Minhaj al-Qā sidin written by Ibnu Qudamah al-Maqdisi, (3) Minhaj al-Muslim written by Abu Bakar Jabir al-Jazairi, (4) al-'Arabiyyah Baina Yadaik written by Abd al-Rahman ibn Ibrahim al-Fa uzan, (5) Ushūl al-Fiqh written by Muhammad ibn Salih al-'Athimain (Aly 2011).

d. Curriculum Implementation: Instruction

Modern Islamic Boarding School Assalaam's learning process is implemented based on the curriculum that has been designe d. It is held in the classrooms, laboratories, mosques, libraries, and also outside the classroom such as under the trees, gardens, and others, at 07.00 until 13:30 pm with a classical system consisting of 24-30 students each class. Classes for male students and female students are separated, but teachers are not separated in implementing the learning. Male teachers can teach students in the women class, and vice-versa, in accordance with their competencies and expertises. 
Fun learning is implemented with the usage of various methods in relevant to the material characteristics, i.e.: lectures method, assignments method, practical method, question and answer method, discussion method, and others.

Evaluation is conducted in form of mid-test, and final-test of semester, which is carried out on a scheduled basis. Besides, every teacher has authority for conducting a self-evaluation, both daily and blocks test. All of these models can be implemented in oral (al-imtihān al-syafahiy), or in writing (al-imtihān al-tahrīry). Oral exam applied to subjects: (1) Arabic (al-mubādathah, al-muthāla'ah, al-mahfüdat, al-tarjamah, al-nahwu, al-sharfu), (2) English (reading, conversation, grammar, vocabulary, translation), (3) the Quran (recitations, al-tajweed, hifz al-Suwar), (4) jurisprudence ( $f i q h$ ' $i b \bar{a} d a h$, praying, the arguments of al-Quran and Hadith), while the written test is applied to all subjects, both the dorm and the school curriculum (Aly 2011).

Modern Islamic Boarding School Assalaam embedded the principle to the student: learning evaluation is implemented for sake of learning; learning is not for exam (al-imtihān li al-ta'allum, laisa al-ta'allum li al-imtihān).

e. Curriculum Evaluation

Curriculum evaluation conducted by the division of the curriculum and the secretariat of the boarding school. The task of this division is to collect and assess reports and inputs provided by caregivers, students, parents. Furthermore, a workshop is held to invite all elements of the institution: foundation, the board of kiayi, director, head of school, teachers, caregivers (Aly 2011).

\section{Analisis and Discussion}

Democratic behavior is not an independent and single variable. Individual's view, and pluralistic thinking is a crucial aspect 
in or der to establish his democratic attitudes and behavior. In this context, the environment (family, school, community) is a very important factor in forming democratic values of the individual. Family is a very important factor in forming the character or value investment in children (Dewantara 1962), because children use a lot of time in the family. Education that consists of in teraction between educators and learners in an effort to help students to achieve educational goal, is responsibility of the parents (Sukmadinata 2011, 2). Schools also have no small role in order to instill values in children (Hamond 2006, 20-21). Society as a non-formal educational institution also has a role in internalization of the child (Hufad and Sauri 2010, 62). Modern Islamic Boarding School Assalaam as boarding school has played a part of the education agency that seeks to instill the values of pluralism to its students. It can be seen from its profile which requires graduates to have five basic capabilities, namely: (1) insight an extensive knowledge, (2) deepen an islamic knowledge, (3) have an attitude of good moral, (4) have the readiness to thrive for the sake of God (jihād fì sabilillah), (5) stand above all parties (Hufad and Sauri 2010).

The struggle to realize a profile of graduates shows that Moder n I s lamic Boarding School A ssalaam highly concerns with values of pluralism. Insight of extensive knowledge and mastery of religious science (tafaqquh fī al-dīn) will have implications to the individuals to understand and appreciate the diffe rences, so they can stand a bove all parties. Bloom et al. confirms that the cognitive factors can contribute to the people's affection, and children's affection will be more confincing when they are reinforced with good cognition (Bloom, Krathwohl, and Masia 1976, 20). The curriculum has a very important position in the educational process. Peshkin asserts that the curriculum is urgent means to change some aspect of society 
(Peshkin 1992, 253). This is also proved by the curriculum of Modern Islamic Boarding School Assalaam, in which students must learn Bidāyat al-Mujtahid wa Nihāyat al-Muqtasid written by Ibn Rushd. This book discusses a field of fiqh (Islamic law) in the various perspectives of madhhab. With this study, students will understand the religious teachings of the various views of the Imams of Fiqh. With comparative insight of islamic doctrine, they would have a broader pattern of thought, have alternative thought to various problems. Moreover, Modern Islamic Boarding School Assalaam also taught ushul fiqh using the Book of Usūl al-Fiqh written by Muhammad ibn Salih al-'Athimain. Usūl al-fiqh which is the study of philosophy of Islamic law, provides a theoretical framework, methodological and philosophical issues in Islamic law.

The desire to create graduates who have an insightfull pluralistic has also been startedsince the admission of students. The admission process of students gives freedom to anyone regardless of the origin, background. They are given the freedom to choose the institutions or education that will be entered. When they were accepted as a student, they were also given the freedom to develop themselves in accordance with talents, interests, both in the dorm and in school. In the perspective of curriculum theory, it is characteristic of concept model of the humanistic curriculum, in which the curriculum serves to provide valuable experience to facilitate the development of private student; and the purpose of education is to foster a dynamic person, to direct toward growth, integrity and autonomy of personality, a healthy attitude towards oneself, others; education direct at children's self-actualization (McNeil 1996, 5).

The values of pluralistic has also been implemented through learning. Modern Islamic Boarding School Assalaam is very attentive to the values of democracy, solidarity, togetherness, 
peace, tolerance. This can be seen from the use of various methods that enable the students to discuss in a dialogue, use freely opinions, convey the idea of learning. Leonard Swidler states that the dialogue is an important medium to foster mutual understanding. With dialogue, people of different faiths can learn good values in any religious teachings. Dialogue does not presuppose the others must have the same vision (Swidler 1984). Academic climate was created to provide a space for students to explore and interact with anyone at the school. Community schools will also support this situation. In the perspective of the theory of internalization, Dewantara (1962) states that there are several methods and stages that can be implemented in accordance with the situation, namely: (1) giving an example, (2) habituation, (3) teaching, (4) command, (5) practical behavior, (6) experience. The first and the second are suitable for children aged 1-7 years, the third and fourth are suitable for ages 7-14 years, while the fifth and sixth way are suitable for children aged 14-21 years. This is also in line with research of Latifah that asserts the modelling has a positive contribution to the moral formation of children. All of them are implemented in Modern Islamic Boarding School Assalaam (Latifah 2011).

Methodologically, Sjarkawi classifies approach of value education into two: traditional and a modern moral education. The first a pproach highly performs an indoctrination and slightly include cognitive factors. The second one is characterized with the usage of the cognitive aspects of moral education, such as critical thinking, moral decision-making problem-based learning, which gives an opportunity to students to move in small groups and gives students opportunities for dialogue and interaction among students (Sjarkawi 2011). In the context of Modern Islamic Boarding School Assalaam, these two approaches have been proportionally implemented in the institution. 
All these proofs confirm that education (including pesantren) has an important role in cultivating values. It has been implemented in Modern Islamic Boarding School Assalaam Surakarta. Education has four potential for future life of the society, namely: to provide a vehicle for implementation of the values in a changing society, to address specific social problems, to increase the ability to accept and implement new alternatives, and education is the best way to guide a human development to contribute to the culture. Fraenkel $(1977,2)$ states that "teaching is value-oriented enterprise". Moreover, Zamakhsyari Dhofier states that:

"The purpose of education in schools is not solely to enrich the mind of students with explanations, but to raise the moral, to train and heightens the spirit, to appreciate spiritual values and humanity, to teach attitude and behavior that is honest and passionate, and to prepare the students for simple life and a clean heart. Each student is taught to accept ethics above religious-ethical conduct of others" (Dhofier 1994).

\section{Conclusion}

Pesantren, which is a type of Islamic educational institution and the oldest one in Indonesia, has an important role in forming character or internalizing values (including values of pluralism) to individuals. This is because the characteristics of pesantren is essentially an integration of "trilogy" educational institutions, namely the family, school and community (or informal, formal and non-formal), which in perspective of value internalization is the most effective model to carry out the mission of education.

The effectiveness of these roles can be seen in Modern Islamic Boarding School Assalaam Surakarta which has shown empirical evidences through the construction of its curriculum, its implementation of learning, and its infrastructure in the institution. They are all designed to internalize pluralistic values 
and designed as an effective instrument to instill values to the student which implements a modern approach rather than traditional one. Therefore, a stigma that pesantren is the exclusive agency as a basis of radicalism should be reviewed. It needs to reconstruct its curriculum and learning process, as well as to arrange the related infrastructure to convince a success of the mission.

\section{Bibliography}

Abdullah, M. Amin. 1995. Falsafah Kalam Di Era Post Modernisme. Yogyakarta: Pustaka Pelajar.

—. 1998. "Problem Epistemologis-Metodologis Pendidikan Islam." In Religiusitas Iptek, edited by Abdul Munir Mulkhan. Yogyakarta: Pustaka Pelajar.

Afrizal. 2007. "Negara Dan Konflik Agraria: Studi Kasus Pada Komunitas Pusat Perkebunan Kelapa Sawit Berskala Besar Di Sumatera Barat.” Masyarakat, Kebudayaan Dan Politik 20 (3): 89-107.

Aly, Abdullah. 2011. Pendidikan Islam Multikultural Di Pesantren: Telaah Terhadap Kurikulum Pondok Pesantren Modern Islam Assalam. Yogyakarta: Pustaka Pelajar.

Azizy, A. Qodri Abdillah. 2000. "Masyarakat Madani: Antara Cita Dan Fakta." In Pendidikan Islam, Demokratisasi Dan Masyarakat Madani. Yogyakarta: Pustaka Pelajar.

Bloom, B.S., D.R. Krathwohl, and B.B. Masia. 1976. Taxonomy of Educational Objectives: Book 2 Affective Domain. London: Longman.

Creswell, JW. 1998. Research Design: Qualitative and Quantitative. Thousand Oaks: Sage Publication.

Dewantara, Ki Hadjar. 1962. Pendidikan. Yogyakarta: Madjelis Luhur Persatuan Taman Siswa. 
Dhofier, Zamakhsyari. 1994. Tradisi Pesantren: Studi Tentang Pandangan Hidup Kiai. Jakarta: LP3ES.

Eliade, Mircea. 1995. Encyclopedia of Religion. New York: Simon \& Schuster Macmilllan.

Elizabeth, Misbah Zulfa. 2007. "Multi Etnisitas Indonesia Dan Potensi Konflik Di Dalamnya.” In Mediasi Dan Resolusi Konflik Di Indonesia: Dari Konflik Agama Hingga Mediasi Peradilan, edited by Musahadi and Mukhsin Jamil. Semarang: Walisongo Mediation Center.

Fraenkel, J.R. 1977. How to Teach about Value. London: Prentice-Hall, Inc.

Hamim, Thoha. 2000. "Islam Dan Civil Society (Masyarakat Madani): Tinjauan Tentang Prinsip Human Right, Pluralism Dan Religious Tolerance." In Pendidikan Islam, Demokratisasi Dan Masyarakat Madani, edited by Ismail SM and Mukti Abdul. Yogyakarta: Pustaka Pelajar.

Hamond, Linda Darling. 2006. Powerful Teacher Education: Lesson from Exemplary Programs. USA: Jossey-Bass.

Hufad, A, and Sofyan Sauri. 2010. "Pendidikan Karakter Berbasis Nilai: Antara Makna, Urgensi Dan Praksis.” In Potret Profesionalisme Guru Dalam Membangun Karakter Bangsa: Pengalaman Indonesia Dan Malaysia, edited by Dadang Sunendar. Bandung: Universitas Pendidikan Indonesia.

Kadarusman. 2006. Nilai-Nilai Dasar Pendidikan Keassalaman. Surakarta: Assalam Press.

Latifah, SU. 2011. Pola-Pola Metode Keteladanan Untuk Penanaman Akblak Peserta Didik Di SD Negeri Pengkol Godean Sleman Yogiakarta. Yogyakarta: Fakultas Tarbiyah UIN Sunan Kalijaga.

Lukens-Bull, Ronald Alan. 2004. Jihad Ala Pesantren Di Mata Antropolog Amerika. Yogyakarta: Gama Media. 
Madjid, Nurcholish. 1998. Mencari Akar-Akar Islam Bagi Pluralisme Modern: Pengalaman Indonesia Dalam Jalan Baru. Bandung: Mizan.

Mardapi, Djemari. 2012. Pengukuran, Penilaian Dan Evaluasi Pendidikan. Yogyakarta: Nuha Litera.

Mas'ud, Abdurrachman. 2002. Menggagas Format Pendidikan Non Dikotomik: Humanisme Religius Sebagai Paradigma Pendidikan Islam. Yogyakarta: Gama Media.

McNeil, John D. 1996. Contemporary Curriculum in Thought and Action. Los Angeles: John Wiley \& Sons, Inc.

Moleong, LJ. 2007. Metodologi Penelitian Kualitatif. Bandung: Remaja Rosdakarya.

Muhaimin. 2009. Pengembangan Kurikulum Pendidikan Agama Islam Di Sekolah, Madrasah Dan Perguruan Tinggi. Jakarta: Rajawali Pers.

Mukhlis. 2004. Inklusivisme Tafsir Al-Azhar. Mataram: IAIN Mataram Press.

Musahadi, ed. 2007. Mediasi Dan Resolusi Konflik Di Indonesia: Dari Konflik Agama Hingga Mediasi Peradilan. Semarang: Walisongo Mediation Centre.

Nafis, Muhammad Muntabihun. 1998. "Pesantren Dan Pluralisme: Upaya Modernisasi Pendidikan Pesantren Menuju Masyarakat Madani." Insani: Jurnal Pemikiran Dan Alternatif Pendidikan 13 (2): 134-66.

Neufeldt, Victoria. 1995. Webster's New World Dictionary American English. Oxford: Pearson Prentice Hall.

Nurchaili. 2010. "Membentuk Karakter Siswa Melalui Keteladanan Guru." Jurnal Pendidikan Dan Kebudayaan 16 (3).

Oladipo, S.E. 2009. "Moral Education of the Child: Whose Responsibility.” J Sec Sei 20 (2): 149-56. 
PESANTREN AS A BASIS FOR INTERNALIZATION ...

Peshkin, Alan. 1992. "The Relationship between Culture and Curriculum: A Many Fitting Thing." In Handbook of Research on Curriculum. New York: MacMillan Publishing Company.

Rachman, Budhi Munawar. 2001. Islam Pluralis. Jakarta: Paramadina.

Rahardjo, Dawam. 1985. Pesantren Dan Pembaharuan. Jakarta: LP3ES.

Ridwan, K, ed. 1993. Ensiklopedi Islam Jilid 4. Jakarta: Ichtiar Baru van Houve.

Rohman, Abdul. 2014. "Junior-Senior High School Based on Pesantren Boarding System.” Jurnal Pendidikan Islam 1 (1): $123-44$.

—. 2016. "Pluralism Based Religious Education for Deradicalization of Religion." Al-Ulum 16 (2).

Shihab, Alwi. 1998. Islam Inklusif, Menuju Sikap Terbuka Dalam Beragama. Bandung: Mizan.

Siahaan, H. 2002. "Karakteristik Dan Faktor Pemicu Konflik Di Daerah Jawa Timur." Masyarakat, Kebudayaan Dan Politik 15 (1): 55-64.

Sjarkawi. 2011. Pembentukan Kepribadian Anak: Peran Moral, Intelektual, Emosional Dan Sosial Sebagai Wujud Integritas Membangun Jati Diri. Jakarta: Bumi Aksara.

Sukmadinata, Nana Syaodih. 2011. Pengembangan Kurikulum: Teori Dan Praktek. Bandung: Remaja Rosdakarya.

Susan, Novri. 2009. Sosiologi Konflik Dan Isu-Isu Konflik Kontemporer. Jakarta: Kencana Prenada Media.

Susetiawan. 2000. Konflik Sosial, Kajian Sosiologis Hubungan Buruh, Perusahaan Dan Negara Di Indonesia. Yogyakarta: Pustaka Pelajar. 
Swidler, Leonard. 1984. "The Dialogue Decalogue; Ground Rules for Interreligious, Interidioligical Dialogue." Journal of Ecumenical Studies 20 (1).

Thoha, Anis Malik. 2007. Tren Pluralisme Agama: Tinjauan Kritik. Jakarta: Kelompok Gema Insani.

Tilaar, HAR, and R Nugroho. 2008. Kebijakan Pendidikan. Yogyakarta: Pustaka Pelajar.

UU Republik Indonesia No. 20.2003.

UUD. 1945. "Preambule of the Constitution of Republic of Indonesia.” Jakarta.

Wahid, Marzuki. 2009. "Islam Dan Pluralisme: Angan-Angan Sosial-Politik Demokratik Piagam Madinah.” Jurnal Islam-Indonesia 1 (1): 89-106.

Yuwinanto, HP. 2004. "Konflik Antar Etnik Di Pedesaan.” Masyarakat, Kebudayaan Dan Politik 17 (3): 103-7.

Zainuddin, M. 2015. "Future Challenges of Religion and Democracy in Indonesia" 09 (02): 151-66. doi:10.15642/ JIIS.2015.9.2.151-166.

Ziemek, M. 1986. Pesantren Dalam Perubahan Sosial. Jakarta: P3M. 